\title{
New records of alien and potentially invasive grass (Poaceae) species for southern Africa
}

\author{
Authors \\ Steven P. Sylvester ${ }^{1}$ (c) \\ Robert J. Soreng ${ }^{2}$ (D) \\ Mitsy D.P.V. Sylvester ${ }^{1}$ \\ Anthony Mapaura ${ }^{3}$ \\ Vincent Ralph Clark ${ }^{3}$

\section{Affiliations \\ ${ }^{1}$ College of Biology and the University, Long Pan Road No. 159, Nanjing, 210037, China. \\ ${ }^{2}$ Department of Botany, National Museum of Natural History, Smithsonian Institution, Washington DC 20560, USA. \\ ${ }^{3}$ Afromontane Research Unit and Department of Geography, University of the Free \\ State, Qwaqwa Campus, Phuthaditjhaba, 9866, South Africa.} \\ Environment, Nanjing Forestry
}

\section{Corresponding Author}

Steven P. Sylvester, e-mail: steven_sylvester@hotmail.com

\section{Dates}

Submitted: 3 July 2020

Accepted: 5 November 2020

Published: 8 July 2021

\section{How to cite this article:}

Sylvester, S.P., Soreng, R.J Sylvester, M.D.P.V., Mapaura, A. \& Clark, V.R., 2021, 'New records of alien and potentially invasive grass (Poaceae) species for southern Africa', Bothalia 51(2) a1. http://dx.doi.org/10.38201/ btha.abc.v51.i2.1

Copyright: (C) 2021. The Authors. Licensee: SANBI. This work is licensed under the Creative Commons Attribution 4.0 International License.
Background: The grasses (Poaceae) of the Flora of Southern Africa (FSA) region (i.e. Botswana, Eswatini, Lesotho, Namibia and South Africa) are relatively well documented, for both native and non-native species. Visiting taxonomic expertise nevertheless reveals new FSA and in-country records, particularly of non-native species. Such records provide an opportunity for improving biosecurity relating to potentially invasive but hitherto undetected non-native Poaceae in the FSA region.

Objectives: To improve floristic data for non-native Poaceae occurring in the FSA region.

Method: Field collections were made, herbarium collections, databases and relevant literature were studied.

Results: New records are presented for non-native grasses that were encountered as locally common populations in the Drakensberg Mountain Centre of Floristic Endemism (DMC, Lesotho and South Africa). Festuca rubra and Agrostis capillaris are newly reported for sub-Saharan Africa and southern Africa and are also the first verified specimens reported for the African continent, with previous reports from northern-most Africa (Morocco, Algeria and/or Tunisia) uncertain. Jarava plumosa, introduced from South America and previously known for the whole of Africa from a single population in the Western Cape of South Africa, is newly reported from the border between the Eastern Cape, South Africa and Lesotho. The ecological implications, including the potential to become invasive, are discussed for each species, with taxonomic notes given to help differentiate them from closely resembling taxa.

Conclusion: These new records of alien grass species raise concerns over their potential ecological impact, particularly as they are found in an area of conservation importance, the DMC. Future efforts to monitor their distribution are of utmost importance.

Keywords: exotic grasses; non-native grasses; Gramineae; Drakensberg Mountain Centre of Floristic Endemism; Lesotho; South Africa

\section{Introduction}

The grass family Poaceae is relatively well-documented for the Flora of Southern Africa (FSA) region (comprising Botswana, Eswatini, Lesotho, Namibia and South Africa), with old and recent country-level treatments (e.g. Gibbs Russell et al. 1990; Fish et al. 2015) that incorporated efforts of numerous researchers who focused on different individual genera (Fish et al. 2015, see references therein), as well as more recent treatments of individual genera e.g. Anthoxanthum L. (Mashau 2016); Festuca L. (Sylvester et al. 2020a); Poa L. (Soreng et al. 2020).

In many countries, grasses have become the most damaging of invasive plants (D'Antonio \& Vitousek 1992; D'Antonio et al. 2011; Gaertner et al. 2014), with knowledge of the distribution and ecology of these non-native grasses 
crucial for effective habitat management (e.g. Gaertner et al. 2014; Visser et al. 2017; Monnet et al. 2020). Visser et al. (2017) notes that there is much uncertainty regarding the identity, numbers of species, distributions, abundances and impacts of alien grasses in the FSA region, with only 37 of the known 256 non-native species in the region considered to be invasive. Despite this lag in non-native Poaceae knowledge, South Africa has some of the most progressive invasive species legislation in the world, including for known invasive Poaceae: 18 species are listed in the National Environmental Management: Biodiversity Act's Alien and Invasive Species Lists (2016).

Even less known is the impact of invasive or alien grasses in the high-elevation Drakensberg Mountain Centre of Floristic Diversity and Endemism (DMC) of southern Africa (Carbutt 2019). The DMC, covering some $40000 \mathrm{~km}^{2}$, contains the only true alpine region in Africa south of Mount Kilimanjaro (Carbutt 2019). These high-elevation Afromontane and alpine areas are renowned for their high levels of plant diversity and endemism, with the DMC hosting \pm 2520 angiosperm species (Carbutt \& Edwards 2004) of which 227 are endemic (Carbutt \& Edwards 2006; Carbutt 2019). This high importance for biodiversity is matched by the socio-ecological importance of these ecosystems, with a significant rangeland-based agrarian community relying on the DMC for their livelihoods (subsistence-based livestock herding being the dominant land-use). Any potential threat to this, such as that posed by potentially invasive alien plants, should be taken very seriously.

During extensive field collecting and ecological research by the authors in the DMC area, new records of alien grass species were discovered that add a further three species to the known flora of the DMC (Carbutt \& Edwards 2004, 2006; Carbutt 2019), and raise concerns over their potential ecological impact.

\section{Materials and Methods}

The new records were collected during extensive fieldwork conducted by SPS, RJS, MDPVS and AM in the DMC between 1 Feb. and 9 Mar. 2020, with specimens deposited in the PRE, NU and US [exported, awaiting accession] herbaria (Herbarium acronyms follow Thiers [continuously updated]). Herbarium study was also conducted at PRE between 13 and 20 Mar. 2020.

\section{Ethical considerations: Permits}

Collecting permits were kindly granted by the Eastern Cape Department of Economic Development, Environmental Affairs and Tourism (DEDEAT), Ezemvelo
KZN Wildlife (EKNZW), and the Lesotho Ministry of Tourism, Environment and Culture - Department of Environment.

\section{Taxonomic Treatment}

Agrostis capillaris L., Sp. Pl. 1: 62 (1753). Agrostis polymorpha var. capillaris (L.) Huds., Fl. Angl. 1: 31 (1778). Trichodium capillaris (L.) Roth, Nov. Pl. Sp. 41 (1821). Type: [Habitat in Europae pratis], Herb. A. van Royen s.n. (lectotype, designated by Widén 1971: 65: L0052645 left-hand specimen [image!]; isolectotype: L [not seen]) (Figures 1, 2).

$=$ Agrostis tenuis Sibth., Fl. Oxon. 36 (1794). Agrostis capillaris Huds., Fl. Angl.: 27 (1762), hom. illeg., non L., 1753. Type: ENGLAND (not located).

Many other heterotypic synonyms (POWO 2020).

Distribution: Of Eurasian origin; introduced into many other temperate areas of the World (POWO 2020, and references therein). This is the first report of the species for sub-Saharan Africa and the FSA region; it may also be the first verified specimen from the African continent, as it is noted with '?' for Morocco and Tunisia by Dobignard and Chatelain (2010: 213) (Figure 2).

New record: SOUTH AFRICA. Eastern Cape: Tiffindell Ski Area, on path to Ben Macdhui summit, S30.6516648 E27.92767, 2745 m alt., side of dirt road through alpine grassland (specifically, Mucina and Rutherford 2006's Lesotho Highland Basalt Grassland vegetation unit in the Grassland Biome), 10 Feb. 2020, S.P. Sylvester et al. 3451 (NU, PRE, US).

Common vernacular names: bent grass (USA); brown top (UK, USA); colonial bent (USA); common bent (UK).

Notes: Agrostis capillaris is generally not considered invasive in the areas where it has been introduced and naturalised, and is not included in the IUCN Global Invasive Species Database (http://www.iucngisd.org/ gisd/). Nevertheless, given the current perceived fragility of the alpine sub-centre of the DMC (Global Mechanism of the UNCCD 2018, 2019; Bentley et al. 2019; Carbutt 2019), the demographics and spatial extent of this species should be examined, and its behavior closely monitored (by e.g. the South African National Biodiversity Institute's (SANBI) Invasive Species Programme). The species was found to be locally frequent and occurs alongside Festuca rubra, also detailed in this paper, and may have been sown as a lawn mix by the Tiffindell Ski Resort to ensure adequate cover of their ski slopes. Other native species such as Lachnagrostis barbuligera (Stapf) Rugulo \& A.M.Molina or Poa binata Nees, which were found in the vicinity, and are just as capable of forming a close sward, should rather be 

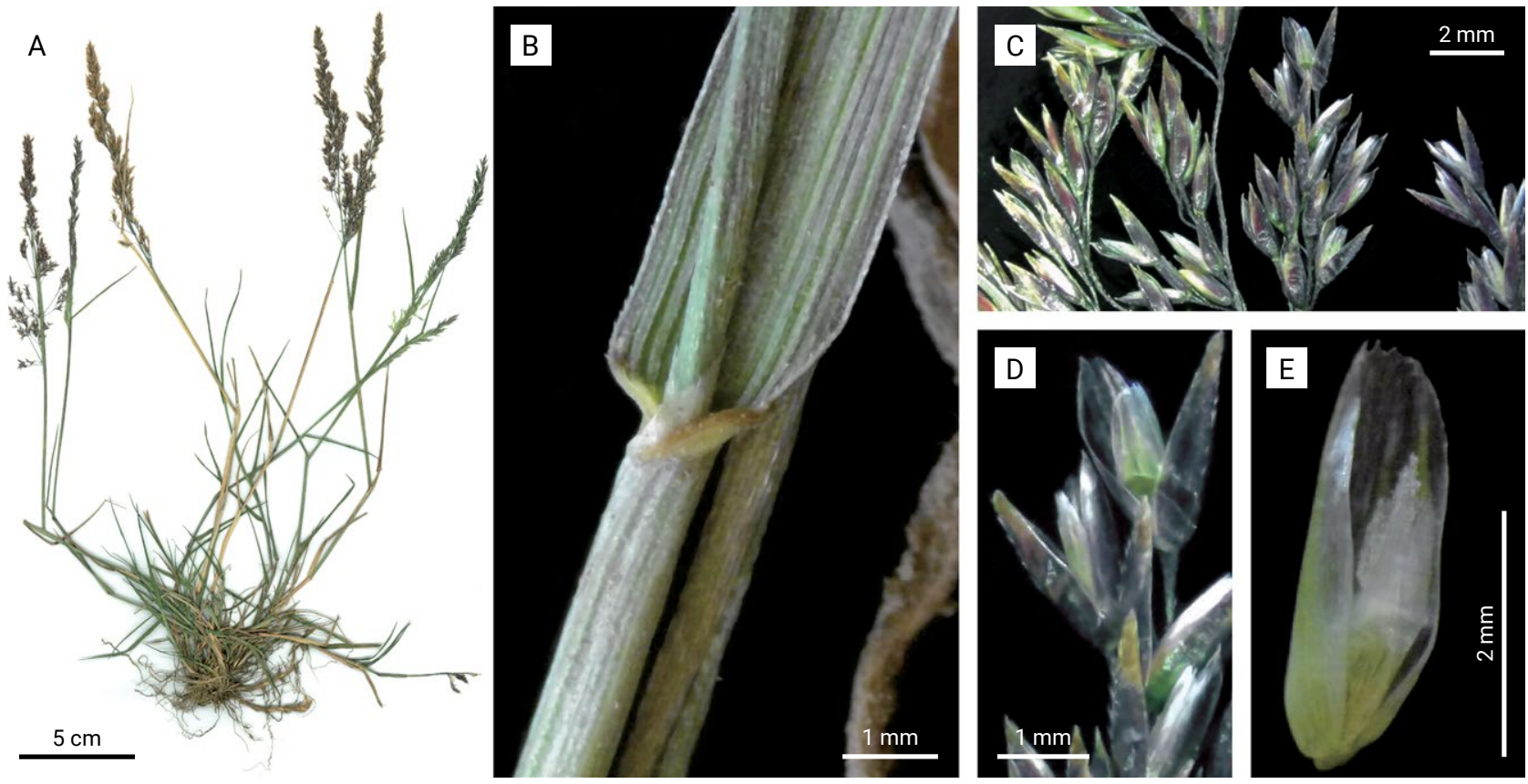

Figure1. Agrostis capillaris; A, whole plant; B, junction of sheath and blade of a tiller [sheath should be expanded to see clearly that the ligule is shorter than broad]; C, inflorescence close-up; D, spikelets, lateral view; E, floret, ventral view, showing the well-developed palea. Image A of S.P. Sylvester et al. 3451 (US), B-E of S.P. Sylvester et al. 3451 (PRE).

used in seeding projects as opposed to these non-native species.

Similar species: Agrostis gigantea Roth, an alien species now naturalised in the FSA region (Fish et al. 2015), is closely related and similar in terms of: plants always with extensively creeping rhizomes, usually without stolons; leaf blades generally flat (A. capillaris often with basal blades involute and culm blades flat); panicles open or only partially contracted after flowering, generally
$>5 \mathrm{~cm}$ long (sometimes as short as $3 \mathrm{~cm}$ in A. capillaris); primary panicle branches without branchlets at least in the proximal half; floret notably shorter than the glumes, usually $1 / 3-3 / 4$ the length of the glumes, without a rachilla prolongation; paleas reaching $(2 / 5-)^{2} / 3-3 / 4$ the length of the lemma; lemmas muticous or with an awn of varying length, ranging from a short straight awn, 0.2-1.0 mm long, to a long geniculate and twisted awn to $4 \mathrm{~mm}$ long, inserted basally, medially or in the upper half of the lem$\mathrm{ma}$, not surpassing or greatly surpassing the glumes.

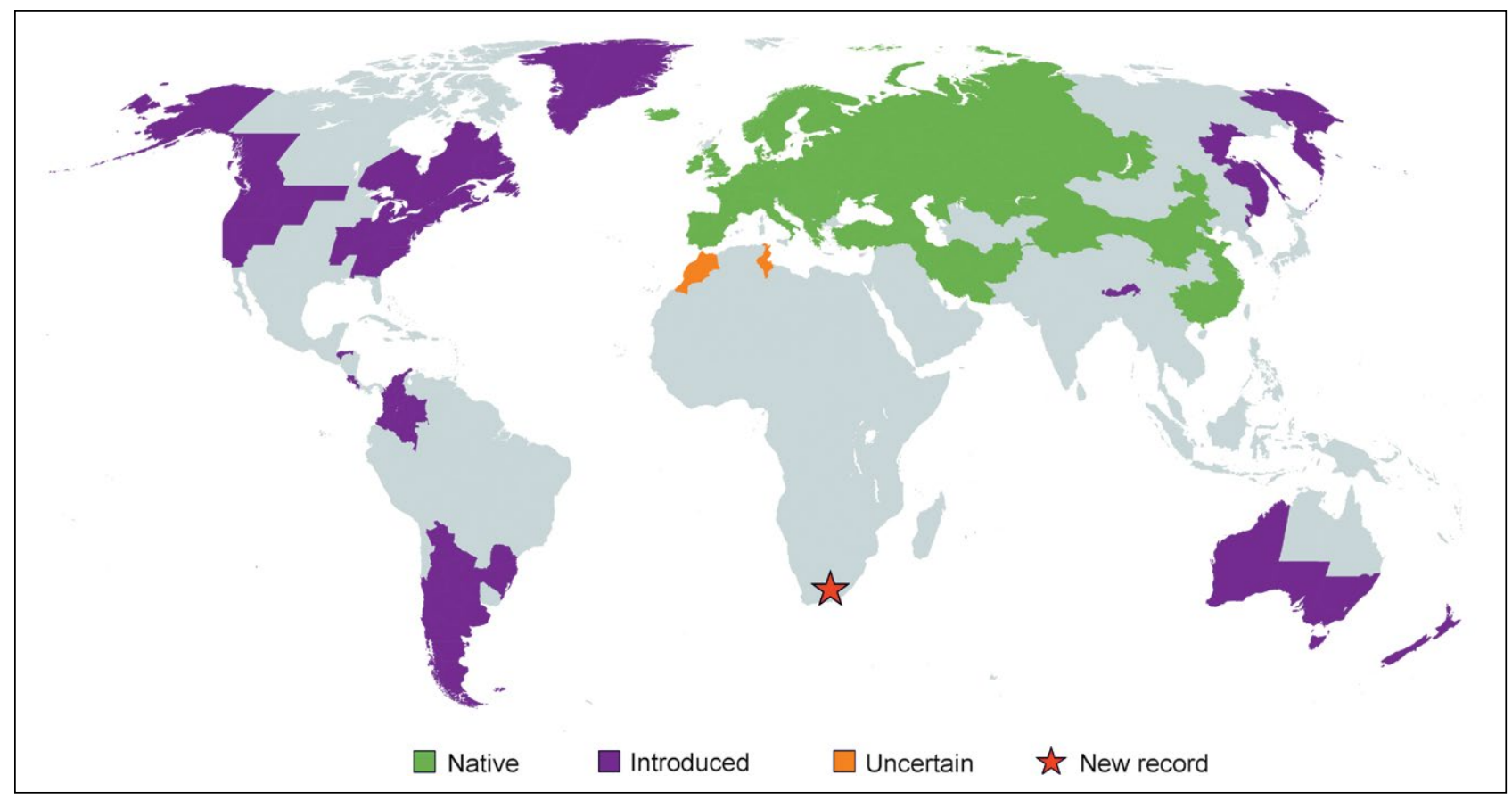

Figure 2. Agrostis capillaris global distribution map, with country- or regional-level shading, taken and modified from POWO (2020). 
Agrostis capillaris is primarily differentiated from A. gigantea by the ligule of the tiller leaves being distinctly shorter than wide [sheath should be expanded to be able to see this clearly] and $\leq 1 \mathrm{~mm}$ long (Figure 1B) (vs. as long as or distinctly longer than wide, $1-3 \mathrm{~mm}$ long in A. gigantea), ligules of culm leaves $0.5-1.5(-2.9) \mathrm{mm}$ long, shorter to sometimes longer than wide (vs. 2-8 $\mathrm{mm}$ long, as long as or distinctly longer than wide in A. gigantea). Agrostis capillaris can also usually be readily distinguished from $A$. gigantea by its shorter size, culms being $10-75(-90) \mathrm{cm}$ tall, and thinner blades of culm leaves $(0.6-) 1.0-4.0(-5.0) \mathrm{mm}$ wide as opened out which are sometimes inrolled (Figure 1) (vs. culms $40-100(-120) \mathrm{cm}$ tall, blades of culm leaves $(2-) 3-8$ $\mathrm{mm}$ wide, always flat in $A$. gigantea) although there are smaller variants of $A$. gigantea with thinner leaves which can superficially resemble $A$. capillaris. In these cases of ambiguity, the ligule will always settle the identity (also see notes and key in Sylvester et al. 2020b).

Agrostis stolonifera L., a species not known from southern Africa, but which is native in temperate Eurasia and northern Africa reaching as far south as Chad, and which is widely introduced elsewhere (POWO 2020, and references therein), also bears similarities to $A$. capillaris. Agrostis stolonifera is primarily differentiated from $A$. capillaris by the ligule of tillers 1-3 $\mathrm{mm}$ long and culm leaves 2.0-6.5 mm long, always distinctly longer than broad. The habit also differs, with A. stolonifera usually extensively stoloniferous with stolons 5-100(-200) cm long [these often not collected as part of herbarium specimens], rhizomes usually absent (vs. extensively rhizomatous, sometimes also stoloniferous, in A. capillaris). Cope and Gray (2009) and Harvey (2007) differentiate A. stolonifera from A. capillaris and A. gigantea mainly based on panicle characteristics, e.g. Cope and Gray (2009) state A. stolonifera has primary panicle branches often bearing branchlets more-or-less from the extreme base but sometimes bare in the lower $1 / 4-1 / 3$, panicle tightly closed after flowering (vs. primary panicle branches bare of branchlets at least in the lower half, panicle open or only partially contracted after flowering in A. capillaris and A. gigantea). However, in the case of $A$. capillaris, panicle contraction after flowering is seen as a somewhat ambiguous differentiating character as it can vary from contracted to open both before and after anthesis. Thus, the form of the ligule is found to be a much more reliable distinguishing character for differentiating these species (also see updated description and key in Sylvester et al. 2020b).

Festuca rubra L., Sp. Pl. 1: 74 (1753). Festuca ovina var. rubra (L.) Sm., Engl. Fl. 1: 139 (1824). Festuca duriuscula var. rubra (L.) Alph. Wood, Amer. Bot. Fl. 2: 399 (1871), nom. illeg. hom. Type: SWEDEN [Hab. in Europa sterilibus siccis]. In paludosis prati regii Upsalia, sin coll. s.n. (lectotype, designated by Jarvis et al. 1987: 301: GB [not seen]) (Figures 3, 4).
Many heterotypic synonyms (POWO 2020).

Distribution: Native range is sub-arctic and temperate Northern Hemisphere (Figure 4). The native range of F. rubra s.I. is noted to extend into northern Africa by POWO (2020), although the subspecies or varieties of F. rubra described from high-elevation Morocco and Algeria have been re-assigned to other species of Festuca (Dobignard 2010). Thus, it is unclear whether F. rubra occurs naturally, or has been introduced, in northern Africa: Dobignard and Chatelain (2010: 296) note '?' for Morocco and the Madeira islands. Our collection from South Africa is therefore possibly the first verified specimen from the African continent. It does, however, occur on sub-Antarctic Marion Island (one of South Africa's two islands in the Prince Edward Islands group), where it is recorded as a major invasive species (Greve et al. 2017). Festuca rubra has also been introduced to Australia, New Zealand, and South and Central America (POWO 2020, and references therein) where it has become naturalised, but is not considered invasive.

New record: SOUTH AFRICA. Eastern Cape: Tiffindell Ski Area, next to ski lift, S30.650718 E27.925683, $2781 \mathrm{~m}$ alt., alpine grassland (specifically, Mucina and Rutherford 2006's Lesotho Highland Basalt Grassland vegetation unit in the Grassland Biome), annually burnt, appears to be seeded with alien species, 11 Feb. 2020, S.P. Sylvester et al. 3455 (NU, PRE, US).

Common vernacular names: red fescue (Canada, UK, USA); strong creeping red fescue (UK).

Notes: Festuca rubra is generally not considered invasive in the areas where it has been introduced and naturalised (except for Marion Island), and is not included in the IUCN Global Invasive Species Database (http:// www.iucngisd.org/gisd/). It was found to be locally common and is likely to have been sown in a seed mixture for maintenance of the Tiffindell ski slopes, which has subsequently spread into nearby alpine grassland (see notes under Agrostis capillaris above).

Traditional circumscription of infraspecific taxa within F. rubra has been brought into question (Saikkonen et al. 2019); although our specimen keys fairly solidly to F. rubra subsp. rubra in the treatments by Hubbard (1984), Cope and Gray (2009), and Darbyshire and Pavlickf (2007), we prefer to present the new record at the species rank here.

Similar species: Festuca rubra is quite distinct and differs from other Festuca s.I. taxa in the FSA region by having the combination of: rhizomes present, very slender, extensively creeping, tillers extravaginal, with cataphylls present (Figure 3B) (vs. extensive creeping rhizomes absent, tillers intravaginal, cataphylls absent in F. africana (Hack.) Clayton [= Pseudobromus silvaticus K. Schum.], F. arundinacea Schreb. [= Lolium 

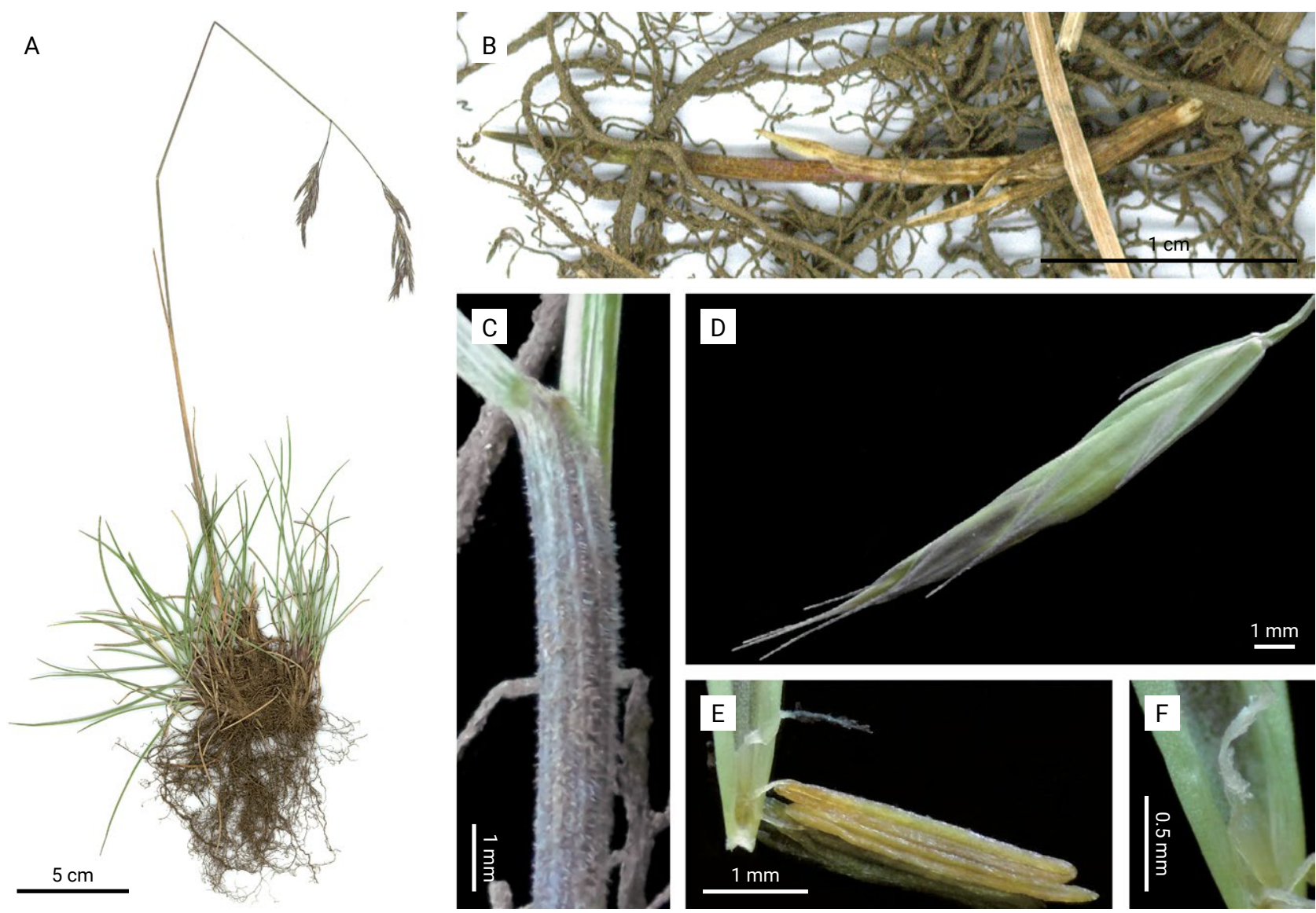

Figure 3. Festuca rubra; A, whole plant; B, lateral-tending rhizome covered in cataphylls; C, leaf sheath and junction with blade of a tiller showing strigose hairs; $D$, spikelet; $E$, base of palea with lemma removed to reveal the ovary and stamens; $F$, close-up of glabrous ovary apex. Images A and B of S.P. Sylvester et al. 3455 (US), C-F of S.P. Sylvester et al. 3455 (PRE).

arundinaceum (Schreb.) Darbysh.], F. caprina Nees, F. costata Nees, F. killickii Kenn.-O'Byrne, F. vulpioides Steud.); basal sheaths entire or splitting into narrow parallel threads (vs. coarsely fibrous in F. costata), usually strigose-hairy (Figure 3C), rarely glabrous (vs. glabrous or scabrous in most; white velvet-hairy in F. scabra Vahl); ligules $0.1-0.5 \mathrm{~mm}$ long (vs. $>1 \mathrm{~mm}$ long in most apart from F. caprina, F. dracomontana H.P.Linder,

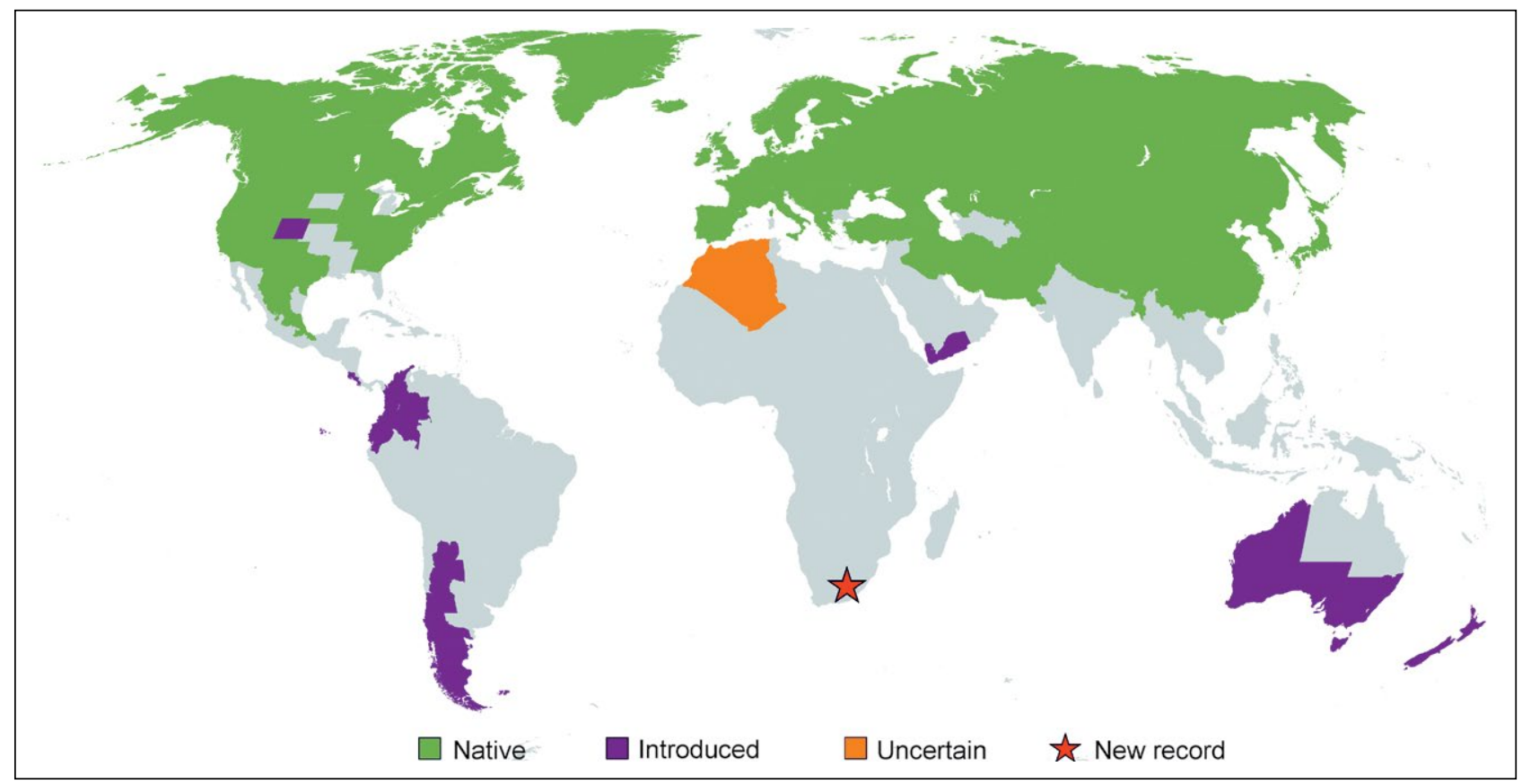

Figure 4. Festuca rubra global distribution map, with country- or regional-level shading, taken and modified from POWO (2020). 
F. drakensbergensis Sylvester, Soreng \& M.D.P.V. Sylvester [Sylvester et al. 2020a], F. exaristata E.B. Alexeev, F. vulpioides); collars non-auriculate (vs. auriculate in F. arundinacea $[=$ Lolium arundinaceum $]$, F. dracomontana, F. vulpioides); blades narrow, conduplicate or rolled, $0.3-1.5(-2.5) \mathrm{mm}$ wide in diameter (vs. flat or relatively broad, [2-]3-15 $\mathrm{mm}$ wide in diameter in most [rarely narrower in F. scabra] apart from F. caprina, F. drakensbergensis, F. exaristata); panicles open or contracted (vs. very open, candelabrum-shaped, in F. longipes Stapf, open or contracted in other taxa); spikelets 3- to 10-flowered (vs. 1-flowered in F. africana [= Pseudobromus silvaticus]; sometimes 2-flowered in other taxa); awns (0.1-)0.4-4.5 mm long (Figure 3D) (vs. 10-20 mm long in F. africana); anthers 1.8-4.5 mm long (Figure 3E) (vs. 0.8-1.8 mm long in F. drakensbergensis, F. exaristata, and rarely F. killickii); ovary apex glabrous (Figure 3F) (vs. hairy in most taxa apart from F. exaristata, F. arundinacea [= Lolium arundinaceum]; incompletely known in F. africana $[=$ Pseudobromus silvaticus]).

Jarava plumosa (Spreng.) S.W.L.Jacobs \& J.Everett, Telopea 7(3): 301 (1997). Calamagrostis plumosa Spreng., Syst. Veg., ed. 16 [Sprengel] 1: 253 (1824). Arundo plumosa (Spreng.) Schult., Mant. 3 (Schultes \& Schultes f.) 604 (1827). Stipa papposa Nees, Fl. Bras. Enum. PI. 2(1): 377 (1829). Stipa papposa Delile, Ind. Sem.
Hort. Monsp. 7 (1849). Stipa delilei Steud., Syn. Pl. Glumac. 1(2): 126 (1854). Achnatherum papposum (Nees) Barkworth, Phytologia 74(1): 11 (1993). Type: [URUGUAY] MONTEVIDEO. F. Sellow s.n. (holotype: B [not seen]; isotypes: US00141669 [image!]) ex herb. Berol., HAL0106794 [image!] ex herb. Berol.) (Figures 5, 6).

= Stipa tenuiflora Phil., Linnaea 33(3-4): 281. 1864. Type: CHILE. Prov. Colchagua: prope Llico, Dec. 1861, L. Landbeck s.n. (holotype: not located; isotypes: BAA00002961 [image!], SGO000000750 [image!]).

= Stipa papposa fo. major Speg., Anales Mus. Nac. Montevideo 100. 1901. Type: not designated.

= Stipa papposa fo. minor Speg., Anales Mus. Nac. Montevideo 100. 1901. Type: not designated.

Distribution: For the entire African continent, J. plumosa was previously known from a single population on the University of Cape Town (UCT) campus collected in 1963 and 1980 (Gibbs Russell et al. 1990; Fish et al. 2015). Our collection in the Eastern Cape extends the species range c. $950 \mathrm{~km}$ eastward. It is also feasible to say that the species has likely established in adjacent Lesotho, which was less than 100 m away on the opposite bank of the Telle River. Jarava plumosa has its native range in austral South America, covering central and eastern Argentina, Chile, Uruguay, to as far north

A
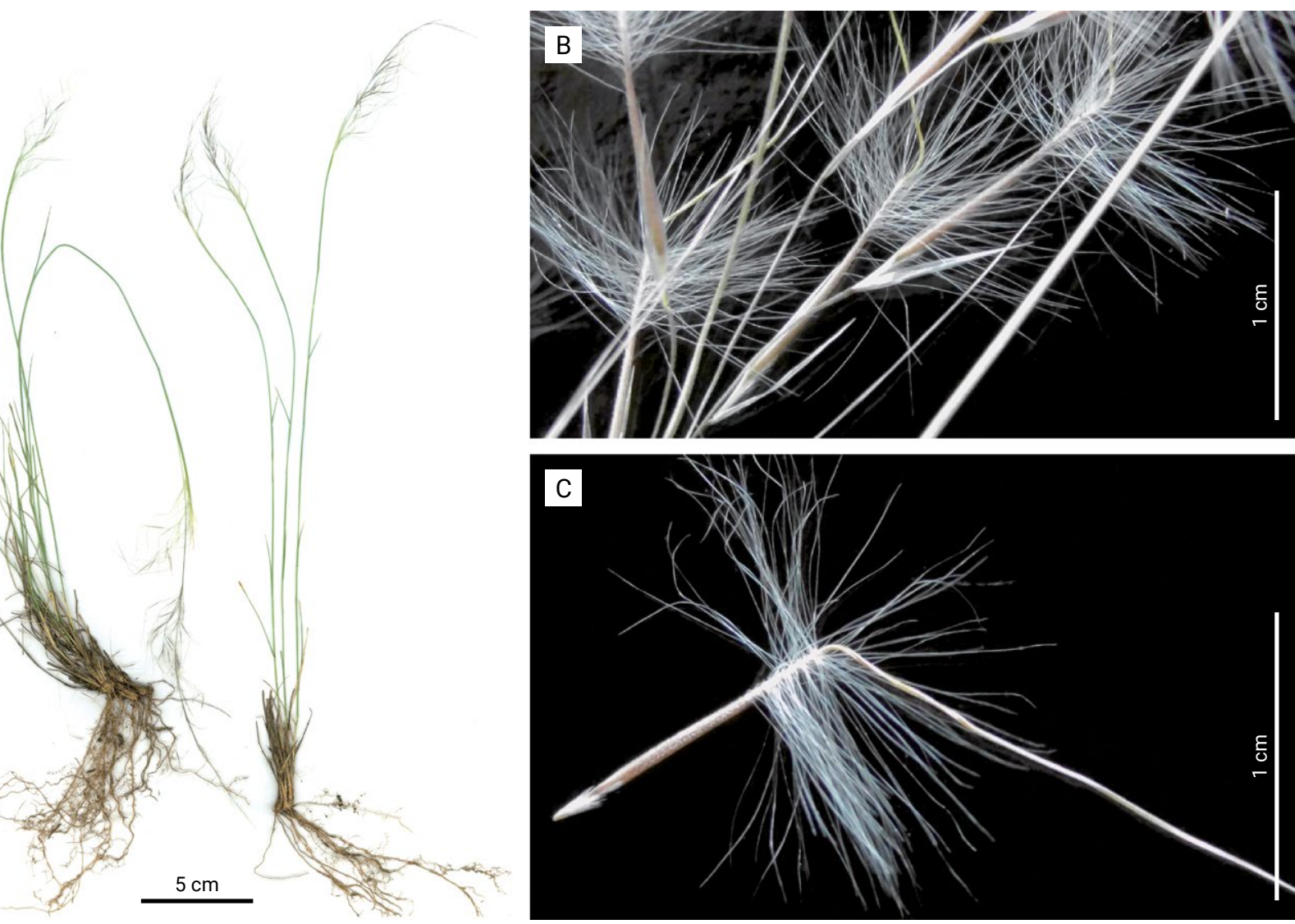

Figure 5. Jarava plumosa; $\mathrm{A}$, whole plant; $\mathrm{B}$, inflorescence close-up; C, floret. Image A of R.J. Soreng et al. ZA-30 (US), B and C of R.J. Soreng et al. ZA-30 (PRE). 


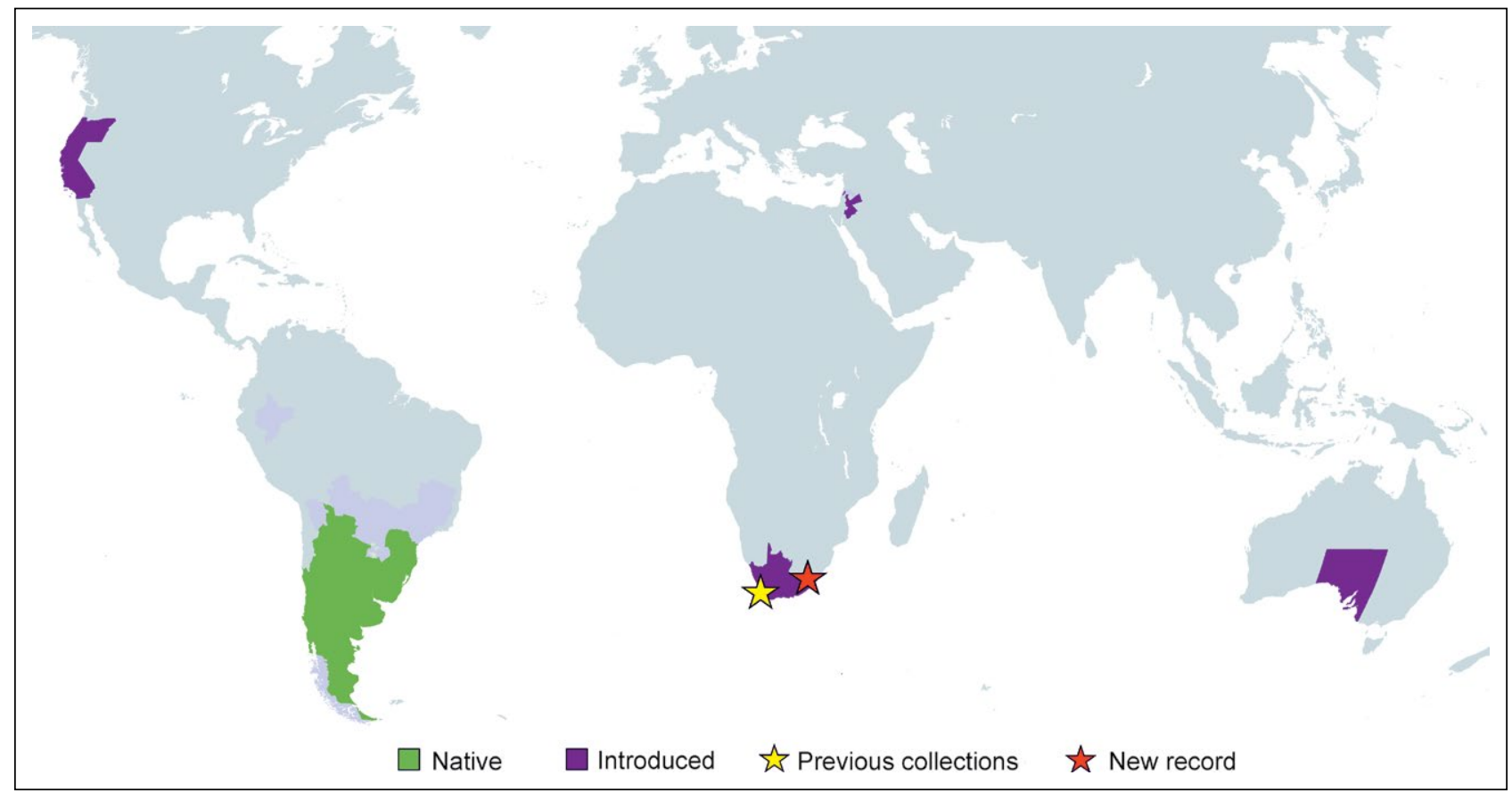

Figure 6. Jarava plumosa global distribution map, with country- or regional-level shading, taken and modified from POWO (2020).

as southern Brazil (Zuloaga et al. 2008; Longhi-Wagner 2015; Figure 6). The species has also been documented as becoming naturalised in Adelaide, Australia (Gardner et al. 1996; Wilson 2009), as well as California, USA (Arriaga 2007), and Palestine (Danin 2004).

New record: SOUTH AFRICA. Eastern Cape: by Telle river on road to Lundeans Nek, near village of Bebeza [or 'Emqheyen' in https://earth.google.com/], S30.518347 E27.649831, 1460 m alt., under Eucalyptus trees by roadside, 9 Feb. 2020, R.J. Soreng et al. ZA-30 (NU, PRE, US, QWA).

Common vernacular names: flechilla mansa, flechilla (Argentina).

Notes: Gardner et al. (1996) noted the vigorous nature of Jarava plumosa and how, despite efforts to remove the plant since as far back as 1968, it continued to establish at the Botanic Gardens of Adelaide and was subsequently found in the South Parklands bordering Adelaide. The first record of J. plumosa outside of its natural range comes from South Africa, from collections made in the UCT campus in 1963 and 1980 (Gibbs Russell et al. 1990). Our discovery of an abundant population of J. plumosa by the side of the Telle River, Eastern Cape, South Africa, points to the likelihood that this species has a wider distribution than previously realised, and has been overlooked. The species exhibits certain traits pointing to its potential to become invasive, such as the apical pappus highly adapted to anemochory, and long awns that easily attach to clothing, fur etc. to aid in zoochory. Closely related species in the genera Nassella (Trin.) É.Desv. and Stipa L. exhibit similar traits, and have successfully become naturalised in many parts of the world, with a few - e.g. Nassella neesiana (Trin. \& Rupr.) Barkworth, N. tenuissima (Trin.) Barkworth, N. trichotoma (Nees) Hack. \& Arechav - that are known invasives causing ecological havoc in many parts of the world, including South Africa (Visser et al. 2017; Mapaura et al. 2020; IUCN Global Invasive Species Database, http://www.iucngisd.org/).

Similar species: In southern Africa, J. plumosa could be mistaken for Stipagrostis anomala De Winter, which also has a pappus-like plume of long hairs, $4-8 \mathrm{~mm}$ long, emerging from the apex of the lemma and/or lower part of the awn. Jarava plumosa can be differentiated from $S$. anomala by the pappus-like hairs being found on the apex of the lemma and base of the awn (vs. hairs restricted to just base of awn in $S$. anomala), callus being obtuse (vs. pungent), and a perennial habit (vs. annual) (Figure 5B-C).

\section{Conclusions}

Three new non-native grass species are added to the flora of the DMC and the FSA: two (Agrostis capillaris and Festuca rubra) in the alpine sub-centre, and one (Jarava plumosa) in the montane sub-centre. Although still apparently highly localised, the unique alpine habitat in southern Africa - with the closest ecological comparison in South Africa and FSA being the Prince Edward Islands - suggests that F. rubra in particular could become a species of concern, and should be monitored with the intention of eradication while still localised. Similarly, the presence of the potentially highly invasive species J .plumosa in the highly degraded and stressed 
xeric rain-shadow region of Telle Bridge requires further population assessment to determine abundance and distribution. All three of these grasses should be looked out for across the DMC for additional undetected populations.

\section{Acknowledgements}

We wish to gratefully thank Nanjing Forestry University, China, and the Afromontane Research Unit (University of the Free State, South Africa) for financial and logistical support; Caroline Mashau, Lyn Fish, and PRE staff for access to the PRE herbarium, discussions of taxa, and supplying collecting paper; and Ralph and Nadine Clark for providing an operations base in South Africa (including during lockdown). We also wish to extend grateful thanks to the permitting authorities and landowners for the relevant permits and permissions to undertake the fieldwork: Ezemvelo KZN Wildlife (uKhahlamba-Drakensberg Park \& UNESCO World Heritage Site), Eastern Cape Parks \& Tourism Authority, Eastern Cape Department of Economic Development, Environmental Affairs \& Tourism, the Kingdom of Lesotho Department of Environment, and Witsieshoek Mountain Lodge/Batlokwa Tribal Authority.

\section{References}

Arriaga M.O., 2007, Jarava Ruiz \& Pav., in Flora of North America Editorial Committee (eds.), Flora of North America North of Mexico 24, pp. 178-181, Oxford University Press, New York, Oxford.

Bentley, L.K., Robertson, M.P. \& Barker, N.P., 2019, 'Range contraction to a higher elevation: the likely future of the montane vegetation in South Africa and Lesotho', Biodiversity and Conservation 28, 131-153. https://doi. org/10.1007/s10531-018-1643-6

Carbutt, C., 2019, 'The Drakensberg Mountain Centre: A necessary revision of southern Africa's high-elevation centre of plant endemism', South African Journal of Botany 124, 508-529. https://doi.org/10.1016/j.sajb.2019.05.032

Carbutt, C. \& Edwards, T.J., 2004, 'The flora of the Drakensberg Alpine Centre', Edinburgh Journal of Botany 60, 581-607. https://doi.org/10.1017/S0960428603000428

Carbutt, C. \& Edwards, T.J., 2006, 'The endemic and near-endemic angiosperms of the Drakensberg Alpine Centre', South African Journal of Botany 72, 105-132. https://doi. org/10.1016/j.sajb.2005.06.001

Cope, T. \& Gray, A., 2009, Grasses of the British Isles. B.S.B.I. Handbook No. 13. Botanical Society of the British Isles, London.

D'Antonio, C.M. \& Vitousek, P.M., 1992, 'Biological invasions by exotic grasses, the grass/fire cycle, and global change', Annual Review of Ecology and Systematics 23, 63-87. https://doi.org/10.1146/annurev.es.23.110192.000431

D'Antonio, C.M., Stahlheber, K. \& Molinari, N., 2011, 'Grasses and forbs', in D. Simberloff \& M. Rejmánek (eds.), Encyclopedia of biological invasions, pp. 280-290, University of California Press, Berkeley and Los Angeles, California.

Danin, A., 2004, Distribution Atlas of Plants in the Flora Palaestina area, The Israel Academy of Sciences and Humanities, Jerusalem.

Darbyshire, S.J. \& Pavlickf, L.E., 2007, Festuca L., in Flora of North America Editorial Committee (eds.), Flora of North America North of Mexico 24, pp. 389-443, Oxford University Press, New York, Oxford.

Dobignard, A., 2010, Notes sur le genre Festuca s. I. en Afrique du Nord', in D. Dobignard \& C. Chatelain (eds.), Index synonymique de la flore d'Afrique du nord 1, pp.
404-425, Éditions des conservatoire et jardin botaniques, Genève.

Dobignard, D. \& Chatelain, C., 2010, Index synonymique de la flore d'Afrique du nord 1, pp. 1-455, Éditions des conservatoire et jardin botaniques, Genève.

Fish, L., Mashau, A.C., Moeaha, M.J. \& Nembudani, M.T., 2015, Identification guide to southern African grasses: an identification manual with keys, descriptions and distributions, Strelitzia 36, South African National Biodiversity Institute, Pretoria.

Gaertner, M., Biggs, R., Beest, M., Hui, C., Molofsky, J. \& Richardson, D.M., 2014, 'Invasive plants as drivers of regime shifts: Identifying high-priority invaders that alter feedback relationships', Diversity and Distributions 20, 733-744. https://doi.org/10.1111/ddi.12182

Gardner, J., Jessop, J.P. \& Symon, D.E., 1996, 'The escape of Stipa papposa'. Journal of the Adelaide Botanic Gardens 17, 173-176. https://www.jstor.org/stable/23873903

Gibbs Russell, G.E., Watson, L., Koekemoer, M., Smook, L., Barker, N.P., Anderson, H.M. \& Dallwitz, M.J., 1990, Grasses of southern Africa, Memoirs of the Botanical Survey of South Africa No. 58.

Global Mechanism of the UNCCD, 2018, Country Profile of Lesotho. Investing in Land Degradation Neutrality: Making the Case. An Overview of Indicators and Assessments, Bonn, Germany.

Global Mechanism of the UNCCD, 2019, Land Degradation Neutrality Target Setting in the Kingdom of Lesotho, Summary Report 2019. Land Degradation Neutrality Target Setting Programme (LDN TSP), viewed 17 June 2020, from https://knowledge.unccd.int/sites/default/files/ Idn_targets/2019-03/Lesotho\%20LDN\%20TSP\%20Country\%20Report.pdf.

Greve, M., Mathakutha, R., Steyn, C. \& Chown, S.L., 2017, 'Terrestrial invasions on sub-Antarctic Marion and Prince Edward Islands', Bothalia 47(2), a2143. https://doi. org/10.4102/abc. v47i2.2143

Harvey, M.J., 2007, Agrostis L., in Flora of North America Editorial Committee (eds.), Flora of North America North of Mexico 24, pp. 633-662, Oxford University Press, New York, Oxford. 
Hubbard, C.E., 1984, Grasses, A guide to their Structure, Identification, Uses and Distribution in the British Isles, Penguin Books, Middlesex, England.

Jarvis, C.E., Stace, C.A. \& Wilkinson, M.J., 1987, 'Typification of Festuca rubra L., F. ovina L. and F. ovina var. vivipara L.', Watsonia 16, 299-302. http://archive.bsbi.org.uk/ Wats16p299.pdf

Longhi-Wagner, H.M., 2015, 'Jarava' in Lista de Espécies da Flora do Brasil. Jardim Botânico do Rio de Janeiro, from http://floradobrasil.jbrj.gov.br/jabot/floradobrasil/FB130039

Mapaura, A., Canavan, K., Richardson, D.M., Clark, V.R. \& Steenhuisen, S., 2020, 'The invasive grass genus Nassella in South Africa: A synthesis', South African Journal of Botany, 135, 336-348. https://doi.org/10.1016/j.sajb.2020.08.031

Mashau, A.C., 2016, 'A synopsis of Anthoxanthum (Poaceae: Pooideae: Poeae) in southern Africa and description of a new subspecies', Kew Bulletin 71, 18. https://doi. org/10.1007/s12225-016-9629-6

Monnet, A.-C., Vorontsova, M.S., Govaerts, R.H.A., Svenning, J.-C. \& Sandel, B., 2020, 'Historical legacies and ecological determinants of grass naturalizations worldwide', Ecography. https://doi.org/10.1111/ecog.04609

Mucina, L. \& Rutherford, M.C., 2006, The vegetation of South Africa, Lesotho and Swaziland, Strelitzia 19. South African National Biodiversity Institute, Pretoria.

POWO (2020) Plants Of the World Online, viewed 13 June 2020, from http://www.plantsoftheworldonline.org/.

Saikkonen, K., Dirihan, S., Väre, H., Saloniemi, I., Cräutlein, M., Leinonen P.H. \& Helander M., 2019, 'Phenotypic and genetic variation in natural populations of Festuca rubra s.l. in Europe', Plant Ecology \& Diversity, 12(5), 441-456. https://dx.doi.org/10.1080/17550874.2019.1654551

Soreng, R.J., Sylvester, S.P., Sylvester, M.D.P.V. \& Clark, V.R., 2020, New records and key to Poa (Pooideae: Poaceae) from the Flora of Southern Africa region, and notes on taxa including a diclinous breeding system in Poa binata', PhytoKeys 165: 27-50; https://doi.org/10.3897/phytokeys.165.55948

Sylvester, S.P., Soreng, R.J., Sylvester, M.D.P.V. \& Clark, V.R., 2020a, 'Festuca drakensbergensis (Poaceae): A common new species in the $F$. caprina complex from the Drakensberg Mountain Centre of Floristic Endemism, southern Africa, with key and notes on taxa in the complex including the overlooked F. exaristata', PhytoKeys 162: 45-69; https://doi.org/10.3897/phytokeys.162.55550

Sylvester, S.P., Cuta-Alarcon, L.E., Bravo-Pedraza, W.J. \& Soreng, R.J., 2020b, 'Agrostis and Podagrostis (Agrostidinae: Poaceae) from páramos of Boyacá, Colombia: synoptic taxonomy including a key to Colombian species', PhytoKeys 151, 107-160. https://doi.org/10.3897/phytokeys.151.50538

Thiers, B. [continuously updated], Index Herbariorum: A global directory of public herbaria and associated staff, New York Botanical Garden's Virtual Herbarium, viewed 5 May 2020, from http://sweetgum.nybg.org/science/ih/.

Visser, V., Wilson, J.R.U., Canavan, K., Canavan, S., Fish, L., Le Maitre, D., Nänni, I., Mashau, C., O'Connor, T.G., Ivey, P., Kumschick, S. \& Richardson, D.M., 2017, 'Grasses as invasive plants in South Africa revisited: Patterns, pathways and management', Bothalia 47(2), 1-29. https://dx.doi. org/10.4102/abc.v47i2.2169

Wilson, A., 2009, Flora of Australia 44A, pp. 1-410, Australian Government Publishing Service, Canberra.

Zuloaga, F.O., Morrone, O., Belgrano, M.J., Marticorena, C. \& Marchesi, E. (eds.), 2008, 'Catálogo de las Plantas Vasculares del Cono Sur', Monographs in Systematic Botany from the Missouri Botanical Garden 107, 1-3348. 